\title{
Variable toxicological response to the loss of OXPHOS through 1- methyl-4-phenylpyridinium-induced mitochondrial damage and anoxia in diverse neural immortal cell lines
}

\author{
Elizabeth A. Mazzio, Youssef I. Soliman, and Karam F. A. Soliman \\ College of Pharmacy and Pharmaceutical Sciences, Florida A \& M University, Dyson Building- \\ Room 104, Tallahassee, FL 32307, USA
}

Karam F. A. Soliman: karam.soliman@famu.edu

\section{Abstract}

Immortal cell lines are used to investigate various aspects of neurodegeneration. These cells display high glycolytic turnover rate and produce an abundant amounts of lactate. Our previous studies indicate that these cells survive the loss of mitochondrial oxidative phosphorylation (OXPHOS) with ample glucose supply. In the current study, we investigate if cell type (w/variation in basal metabolic rate (MR)), can alter glucose utilization patterns which in turn may affect $\mathrm{LC}_{50}$ for the mitochondrial toxin 1-methyl-4-phenylpyridinium $\left(\mathrm{MPP}^{+}\right)$in various cell lines. The data obtained indicate that cell lines MRs examined were generally consistent with the average of species adult body weight where mouse N-2A > rat-PC-12 > human SH-SY5Y. A higher MR was associated with accelerated utilization of glucose and earlier cell death with $\mathrm{MPP}^{+}: \mathrm{LC}_{50}$ mouse $=294 \mu \mathrm{M}$, rat $=695 \mu \mathrm{M}$, and human $=5.25 \mathrm{mM}$ at $24 \mathrm{~h}$. Cell death appears to be a function of the velocity by which glucose disappears, leading to the failure of glycolysis and subsequent halt of energy production. Similar effects were also observed at higher plating densities where the demand for glucose is amplified. A time-lapse study of $\mathrm{MPP}^{+}$toxicity $(0-36 \mathrm{~h})$ in N-2A cells indicates that an anaerobic shift occurs as early as $2 \mathrm{~h}$ (evidenced by a rise in lactate), followed by a descent in glucose concentrations at $4 \mathrm{~h}$ and exhaustion of glucose supplies at $22 \mathrm{~h}$ which was associated with the first detectable sign of cell death. It was also noted that $\mathrm{MPP}^{+}$toxicity was not associated with the generation of reactive oxygen species $\left(\mathrm{O}_{2}^{-}, \mathrm{H}_{2} \mathrm{O}_{2}\right.$, and $\left.\mathrm{NO}_{2}\right)$ and was not attenuated by adding catalase or superoxide dismutase to the media. On the other hand, $\mathrm{MPP}^{+}$toxicity was reversed by providing additional supply of glucose, pyruvate \pm mitochondrial monocarboxylate transporter blocker ( $\alpha$-cyano-4-HCA), or pyruvate \pm pyruvate dehydrogenase inhibitor (octanoyl-CoA), suggesting that the exclusive anaerobic survival compensates for the loss of OXPHOS by $\mathrm{MPP}^{+}$. To examine if neuroblastoma were capable of surviving the deprivation of $\mathrm{O}_{2}$ for $24 \mathrm{~h}$, a range of hypoxia to anoxia was established with various concentrations of dithionite. The data suggest that cell lines examined continue to thrive when incubated with high-glucose media $(25 \mathrm{mM})$. In summary, vulnerability of immortal neuroblastoma cell lines to $\mathrm{MPP}^{+}$toxicity is dependent upon glucose concentrations within the media and cell MR, which indirectly dominates the velocity of glucose use and its end point disappearance, leading to cell death by ergogenic failure.

\section{Keywords}

Glucose; Hypoxia; Glycolysis; MPP+; Tumor; PC-12; Neuroblastoma 2-A; SH-SY5Y; OXPHOS; Anaerobic 


\section{Introduction}

Rat pheochromocytoma PC-12 cells, human SH-SY5Y, and mouse N-2A neuroblastoma cells are commonly used for in vitro studies pertaining to neurological disease. These three cell lines are of malignant phenotype, which are believed to differ from normal cells given the characteristic of glycolytic dependence (Warburg effect), an inherent mitochondrial mutation (Sun et al. 2009; Pan and Mak 2007), and a propensity to thrive under hypoxic microenvironments (Gatenby and Gawlinski 2003; Godinot et al. 2007; Griffiths et al. 2001; Liu et al. 2002). When exposed to hypoxia, tumor cells will undergo genetic adaptation leading to aggressive malignancy, metastasis, and a resistance to chemotherapy (Airley and Mobasheri 2007; Sullivan et al. 2008; Tóth 2007). Tumor cells are equipped to carry out high-volume anaerobic metabolism due to over-expression of glucose transporters (GLUT1; Airley and Mobasheri 2007) and glycolytic enzymes (hexokinase, phosphofructokinase, and pyruvate kinase), all of which enhance the glycolytic function (Hennipman et al. 1988; Ikezaki et al. 1992; Koukourakis et al. 2006). The accelerated pace at which anaerobic metabolism proceeds in tumor cells is the cause of the development of positron emission tomography ${ }^{18} \mathrm{~F}-$ fluorodeoxyglucose which is commonly used in cancer diagnosis (Maublant et al. 1998; Burstein et al. 1998).

Cells with inhibited mitochondrial function will have a drop in oxidative phosphorylation (OXPHOS), and its energy requirements would have to be met through enhancing anaerobic glycolysis. There is no question that accelerated anaerobic metabolism is observed in both immortal and primary neurons upon mitochondrial insult. For example, administration of 1methyl-4-phenyl-1,2,3,6-tetrahydropyridine (MPTP) in animals invokes accelerated anaerobic glycolysis evidenced by a rise in striatal lactate (Koga et al. 2006) and expedited glucose utilization patterns (as detected with $\left[2-{ }^{14} \mathrm{C}\right]$ deoxyglucose) in the $\mathrm{SN}$ pars compacta and locus coeruleus, areas most affected in PD (Palacios and Wiederhold 1984). The same anaerobic shifts also occur in primates where administration of MPTP leads to accelerated uptake of 2deoxy-D-[ $\left[{ }^{14} \mathrm{C}\right]$ glucose in $\mathrm{SN} /$ globus pallidus areas corresponding to dopaminergic neurodegeneration (Palombo et al. 1988; Schwartzman and Alexander 1985; Schwartzman et al. 1998). These effects are also consistently observed in various models such as excised rat brain slices where $\mathrm{MPP}^{+}$causes a rise in striatal glucose metabolism (Maruoka et al. 2007) and in immortal neuroblastoma where $\mathrm{MPP}^{+}$stimulates a rise glycolysis and a spike in the production of lactate (Basma et al. 1992).

There is a discrepancy in the reported $\mathrm{LC}_{50}$ for $\mathrm{MPP}^{+}$in vitro ranging from micromolar to 10 $\mathrm{mM}$ sometimes in similar immortal neuroblastoma cell lines (Mazzio and Soliman 2003a; Jung et al. 2009; Seyfried et al. 2000; Pizarro et al. 2010; Tang et al. 2010). The large range variation in $\mathrm{LC}_{50}$ for $\mathrm{MPP}^{+}$is likely the result of different experimental variables that ultimately alter media glucose concentrations. Given that a heightened rate of glycolysis is required to sustain ATP production through substrate level phosphorylation during $\mathrm{MPP}^{+}$-mediated loss of OXPHOS, any influential factor that alters glucose concentrations could also alter vulnerability to the toxin. In this study, we attempt to elucidate if various base metabolic rates, plating densities, and media glucose concentrations govern $\mathrm{LC}_{50}$ in mouse $\mathrm{N}-2 \mathrm{~A}$, rat-PC-12, and human SH-SY5Y cells during the exposure to $\mathrm{MPP}^{+}$. We have also examined the extent to which different neuroblastoma cells can survive in the complete absence of $\mathrm{O}_{2}$ when ample glucose is sustained.

\section{Materials and methods}

Cell lines were purchased from American Type Culture Collection, ATCC (Manassas, VA, USA). Dulbecco's modified Eagle medium (DMEM), L-glutamine, fetal bovine serum, heatinactivated (FBS), phosphate-buffered saline (PBS), Hank's balanced salt solution (HBSS), 
and penicillin/streptomycin were purchased from Fischer Scientific, Mediatech, (Pittsburgh, PA, USA). All other chemicals and research supplies were purchased from Sigma Chemical (St Louis, MO, USA).

\section{Cell culture and sample preparation}

Neuro-2A (N-2A) murine brain neuroblastoma cells, rat pheochromocytoma (PC-12), and human SH-S5Y5 brain neuroblastoma were used in this study. PC-12 cells were further isolated from a sub-clone of plastic adhering cells which displayed spontaneous neurite extensions and similar response to $\mathrm{MPP}^{+}$toxicity as PC-12 cells that were differentiated with NGF. Furthermore, human SH-S5Y5 brain neuroblastoma cells were not differentiated as it has been reported that differentiation with all-trans-retinoic acid does not intensify $\mathrm{MPP}^{+}$toxicity (Cheung et al. 2009). Cells were grown in DMEM with phenol red, 10\% FBS (v/v), $4 \mathrm{mM}_{\mathrm{L}-}$ glutamine and penicillin/streptomycin (100 Units $/ 0.1 \mathrm{mg} / \mathrm{ml})$, and $20 \mu \mathrm{M}$ sodium pyruvate. Cells were grown at $37^{\circ} \mathrm{C}$ in $5 \% \mathrm{CO}_{2}$ atmosphere, scraped, and sub-cultured every $2-5$ days. Experimental plating media contained low glucose $(5.5 \mathrm{mM})$, no phenol red, and supplemented with FBS $(1.8 \%)$, penicillin/streptomycin $(100 \mathrm{U} / 0.1 \mathrm{mg} / \mathrm{ml}) / 4 \mathrm{mM}_{\mathrm{L}}$-glutamine, and for routine experiments, the cells were plated at $0.5 \times 10^{6}$ cells $/ \mathrm{ml}$. Energy substrates, $\mathrm{MPP}^{+}$, and sodium dithionite were prepared freshly in sterile HBSS + $10 \mathrm{mM}$ HEPES (pH 7.4). Previously, we had determined that the preparation of pyruvate should be accomplished so that it is maintained in its acidic form-to allow transport into the cell. This can be achieved by slight neutralization so that the $\mathrm{pH}$ is maintained with a range where acidity is not the basis for cell toxicity. For these experiments, pyruvic acid stock solutions were prepared by combining sodium pyruvate with pyruvic acid ( $\mathrm{pH} 3.85$ ) in the HEPES buffer, followed by preparation of serial dilutions which were then added to the cells at $20 \%(\mathrm{v} / \mathrm{v})$.

\section{Glucose analysis}

Briefly, glucose was quantified as previously described (Mazzio and Soliman 2003a) using an enzymatic assay containing equal volume of glucose oxidase $(20 \mathrm{U} / \mathrm{ml})$ and a chromogenic solution containing $1 \mathrm{mM}$ vanillic acid, $500 \mu \mathrm{M}$ of 4-aminoantipyrine, and four purpurogallin units per milliliter of horseradish peroxidase type II. Glucose was quantified at $550 \mathrm{~nm}$ on a UV microplate spectrophotometer (model 7600, version 5.02, Cambridge Technologies Inc., Watertown, MA, USA). Protein was determined using the Lowry protocol (Lowry et al. 1951), and the data were expressed as micromoles per milligram protein, volume equivalent or the percent of control.

\section{Cell viability and cell death}

Resazurin (almar blue) indicator dye was used as a measure of viable cell count (Evans et al. 2001; Mazzio and Soliman 2003a). Reduction of the dye by viable cells reduces the amount of oxidized form and increases the amount of fluorescent intermediate (resorufin). Quantitative analysis of dye conversion at a time point prior to full reduction of the controls was used to measure metabolic rate among the various cell lines. Metabolic rate was established by analyzing the conversion of the dye (Fluorescent Intensity (FI))/(Fixed Time Point, $4 \mathrm{~h}$ ) under identical culture conditions and plating density. FI was measured using a microplate fluorometer (model 7620, version 5.02, Cambridge Technologies Inc.) with settings adjusted to [550/580] ([excitation/emission]) wavelengths. Fluorescein diacetate and propidium iodide staining were used to determine cell viability and cell death (Mazzio and Soliman 2003a). Photographic data were captured using an Olympus IX-70 inverted microscope equipped with an MD35 Electronic Eyepiece (Zhejiang Jincheng Sci \& Tech Co., Ltd, China) and image capture using C-imaging systems PCI-Simple software (Compix Inc. Cranberry Township, PA, USA). 


\section{Lactic acid}

Lactic acid was quantified by HPLC using a Shimadzu SCL-10A Controller, a LC-10AT pump (flow rate $=0.6 \mathrm{ml} / \mathrm{min})$, an aliphatic Acclaim OA organic acid column, $(5 \mu \mathrm{m}: 4 \times 250 \mathrm{~mm}$ ) where the mobile phase consisted of $10 \mathrm{mM} \mathrm{Na}_{2} \mathrm{SO}_{4}, \mathrm{pH} 2.65$, adjusted with methanesulfonic acid using an SPD-M10A VP diode array detector with settings at $211 \mathrm{~nm}$.

\section{Oxygen respiration}

Whole cell mitochondrial $\mathrm{O}_{2}$ consumption was analyzed using a Clark electrode (Hansatech Instruments Ltd., Norfolk, England). The electrode quantifies concentrations of dissolved $\mathrm{O}_{2}$ in the medium as a means to assess mitochondrial respiration. The electrode was calibrated with air-saturated deionized water (air line) and deionized water containing sodium dithionite (nitrogen line). The samples (cell media after experimental treatment) or control blanks were loaded into the chamber jacket at $25^{\circ} \mathrm{C}$. After the instrument was stabilized and equilibrated, the raw data were acquired as nanomoles of $\mathrm{O}_{2}$ per milliliter and converted to percentage of control values.

\section{Nitrite determination}

Quantification of nitrite $\left(\mathrm{NO}_{2}^{-}\right)$was determined by a spectrophotometric procedure (Park and Murphy 1994). Briefly, the Griess reagent was prepared by mixing an equal volume of $1 \%$ sulfanilamide in $0.5 \mathrm{~N} \mathrm{HCl}$ and $0.1 \% \mathrm{~N}$-(1-naphthyl) ethylenediamine in deionized water. The Griess reagent was added directly to the cell suspension and incubated under reduced light at room temperature for $10 \mathrm{~min}$. Samples were analyzed at $550 \mathrm{~nm}$ on a UV micro-plate spectrophotometer (model 7600, version 5.02, Cambridge Technologies). Controls and blanks were measured simultaneously, and subtracted from the final value to eliminate interference. A standard curve was generated from a range of dilutions of sodium nitrite $(1-100 \mu \mathrm{M})$ prepared in the plating medium. Protein level of each sample was determined using the Lowry method (Lowry et al. 1951). The data were calculated as nanomolar $\mathrm{NO}_{2}{ }^{-}$per milligram protein.

\section{Hydrogen peroxide and superoxide assays}

Hydrogen peroxide $\left(\mathrm{H}_{2} \mathrm{O}_{2}\right)$ level was measured by the modification of a previously described method (Holt et al. 1997). After experimental treatment, sample supernatants were assessed for $\mathrm{H}_{2} \mathrm{O}_{2}$ using a peroxidase-linked continuous assay. The chromogenic solution contained (final working concentration) $1 \mathrm{mM}$ vanillic acid, $500 \mu \mathrm{M} 4$-aminoantipyrine, and horseradish peroxidase (4 U/ml) in PBS with $2 \mathrm{mM}$ of HEPES ( $\mathrm{pH} 7.4$ ). The chromogenic reagent was added to each sample and incubated for $10 \mathrm{~min}$ at $37^{\circ} \mathrm{C}$. Samples were analyzed at $550 \mathrm{~nm}$ on a UV Microplate Spectrophotometer (model 7600, version 5.02, Cambridge Technologies). Controls and blanks were measured simultaneously and subtracted from the final value to eliminate interference. Protein was assessed by the Lowry method (Lowry et al. 1951). Final data were expressed as nanomolar $\mathrm{H}_{2} \mathrm{O}_{2}$ per milligram protein or volume equivalent. Superoxide was determined using a nitroblue tetrazolium (NBT) assay. Briefly, a stock solution of $1 \mathrm{mg} / \mathrm{ml} \mathrm{NBT}$ was prepared in HBSS with $10 \mathrm{~mm}$ HEPES buffer, $\mathrm{pH}$ 7.6. The reagent was added to the samples $(11 \%, v / v)$, incubated for $30 \mathrm{~min}$ at $37^{\circ} \mathrm{C}$, and quantified by measuring purple NB-diformazan at $560 \mathrm{~nm}$ on a UV microplate spectrophotometer.

\section{Data analyses}

Statistical analysis was performed using Graphpad Prism (version 3.0, Graphpad Software Inc., San Diego, CA, USA). The data were expressed as the mean \pm SEM $(N=4)$ for each group. Significance of difference between the groups was assessed using one-way analysis of variance (ANOVA), followed by a Tukey post-hoc means comparison test. The lethal concentrations $\left(\mathrm{LC}_{50}\right)$ were established from dose-dependent data with Origin Lab 7.5 SR6, and significance 
of difference between the groups was assessed using one-way ANOVA, followed by a Tukey post-hoc means comparison test.

\section{Results}

Metabolic diversity among the various cell lines studied was determined under strictly controlled experimental conditions (Fig. 1). The data experiments were conducted at the same time, with the same media, in 96-well plates, with identical culture conditions, timeline, and procedure. The data obtained show that at equal plating densities $\left(0.5 \times 10^{6} \mathrm{cell} / \mathrm{s} / \mathrm{ml}\right)$ of 50,000 cells per well, differences were evidenced in metabolic rate (conversion from almar blue $\rightarrow$ resorufin/4 h), glucose remaining (micromolar per milligram protein), and extent of $\mathrm{O}_{2}$ consumed (nanomoles per milliliter) after $24 \mathrm{~h}$ (Fig. 1). The data in Fig. 1 corroborate that a higher metabolic rate corresponds to less glucose remaining in the media and greater $\mathrm{O}_{2}$ consumed in the order of mouse > rat > human. In our study, we used rat PC-12 cells that were derived from a sub-clone plastic-adhering variant in our laboratory. The obtained results indicate that all cell lines displayed neurite extensions and adhered to plastic without the use of growth factors. In the next experiment, we show that the $\mathrm{LC}_{50}$ for $\mathrm{MPP}^{+}(0-10 \mathrm{mM})$ over $24 \mathrm{~h}$ were lowest in cells having higher metabolic rate (Fig. 2a), which was significantly exacerbated after $48 \mathrm{~h}$ (Fig. 2b). A similar trend was observed for the effects of $\mathrm{MPP}^{+}$on hampering mitochondrial $\mathrm{O}_{2}$ consumption (Fig. 2c).

The data presented in Figs. 1 and 2 suggest that the higher cellular metabolic rate, the faster is glucose disappearance, where this drop exacerbates $\mathrm{MPP}^{+}$toxicity as a result of a shift toward anaerobic glycolysis. In order to evaluate the mechanism of cell death as it relates to the compromise of energy as a result of $\mathrm{MPP}^{+}$, we chose to use $\mathrm{N}-2 \mathrm{~A}$ cells due to its sensitivity, robust metabolic activity, ease of use, and because they are of neural origin from a spontaneous malignant tumor. Time-lapse analysis $(0-36 \mathrm{~h})$ of $\mathrm{MPP}^{+}$toxicity in the most vulnerable cell line N-2A cells was conducted (Fig. 3). In addition, Fig. 3 shows that $\mathrm{MPP}^{+}(500 \mu \mathrm{M})$ caused a time-dependent depletion of glucose concentrations, also accompanied by a rise in lactate where cell death was tantamount to exhaustion of glucose supplies (Fig. 3, right panel vs. left panel, control). The data obtained indicate that $\mathrm{MPP}^{+}$accelerates glucose depletion, to which a 95\% drop was associated with detectable signs of cell death. These findings indicate that a loss of OXPHOS by $\mathrm{MPP}^{+}$precipitates cell death by accelerating anaerobic glycolysis, leading to depletion of glucose. Given that higher cell densities should expedite a loss of glucose concentrations in vitro, one would expect to see greater cell death from $\mathrm{MPP}^{+}$accordingly (Fig. 4). The data in Fig. 4 provide evidence to suggest this is the case, where $61 \%$ greater toxicity occurs from $\mathrm{MPP}^{+}(500 \mu \mathrm{M})$ in N-2A cells after $24 \mathrm{~h}$, when density was doubled to 50,000 cells/well in 96-well plates. In order to corroborate the data from Fig. 3 (time-lapse analysis), metabolic changes over a range of $\mathrm{MPP}^{+}(0-500 \mu \mathrm{M})$ in N-2A cells were measured after $24 \mathrm{~h}$ (Fig. 5). These findings show that a decline in glucose and a rise in lactate are critical events parallel to cell death. There was no evidence to confirm the presence of a number of free radicals or its association with cell death. Thus far, the data obtained indicate that the toxic effects of $\mathrm{MPP}^{+}$are highly due to the loss of glucose supplies in the media, to which metabolic rate and cell count control the former.

The results of experiments presented in Figs. 1, 2, 3, 4, and 5 were achieved using low-glucose standard experimental media: DMEM-phenol red containing 1,000 mg/l glucose, equiv 5.5 $\mathrm{mM}$ glucose. In the next experiment, DMEM was prepared fresh from powdered media and supplemented with $1 \mathrm{mM}$ glucose (very low glucose). Here, we assess the protective effects of glucose, pyruvate, or antioxidant enzymes (Fig. 6). The toxicity of $\mathrm{MPP}^{+}$in very low glucose media was reversed by $10 \mathrm{mM}$ glucose or pyruvate, but not $10 \mathrm{U} / \mathrm{ml}$ of superoxide dismutase (SOD) or catalase. To further demonstrate that the mitochondria may be an expendable organelle, the protective effects of pyruvate against $\mathrm{MPP}^{+}$were monitored in the presence or 
absence of a mitochondrial monocarboxylic acid transport blocker cyano-4-hydroxycinnamate ( $\alpha$-cyano-4-HCA) in N-2A cells (Fig. 7a, left panel). These findings indicate that blocking pyruvate entry into the mitochondrial to sustain the tricarboxylic acid cycle (TCA) is not necessary to sustain the protective effects of pyruvate because anaerobic glycolysis through lactic acid dehydrogenase (LDH) alone is adequate to compensate for the effects of a mitochondrial toxin. These effects were also similar to those observed in the presence of a pyruvate dehydrogenase complex inhibitor (octanoyl-CoA; Fig. 7a, right panel). In order to examine the effects of $\alpha$-cyano-4-HCA alone on glucose utilization in $\mathrm{N}-2 \mathrm{~A}$ controls, it was found that blocking pyruvate as a substrate for the TCA cycle reduced mitochondrial $\mathrm{O}_{2}$ consumption as would be expected and slightly augmented glucose utilization (Fig. 7b), indicating that the concentrations used were adequate for analysis in Fig. $7 \mathrm{a}$.

In order to establish that the examined cells are capable of surviving in high-glucose media without mitochondrial use, the effects of $\mathrm{O}_{2}$ deprivation by sodium dithionite addition to the plating media was evaluated (Fig. 8). The data show that cell survival continues to occur unabated in the complete absence of dissolved $\mathrm{O}_{2}$. To confirm these findings, photographic analysis of cell viability with fluorescein diacetate and propidium iodide was obtained (Fig. 9). A cell death control was established for photographic analysis by inducing toxicity by addition of $700 \mu \mathrm{M}$ of $\mathrm{H}_{2} \mathrm{O}_{2}$. In summary, these findings suggest that glucose plays a foremost critical role in cell survival during loss of OXPHOS incurred by either the presence of a mitochondrial toxin or lack of $\mathrm{O}_{2}$ in neuroblastoma where vulnerability should take into consideration cell density, metabolic rate, and concentrations of glucose within the experimental design.

\section{Discussion}

The current study investigates the extent by which metabolic patterns of immortal neural cell lines regulate glucose concentrations, which underlie altered vulnerability to mitochondrial toxicity in vitro. The data obtained in the study suggest that cell death upon exposure to $\mathrm{MPP}^{+}$appears to be a direct function of a greater metabolic rate and cell density, which indirectly controls velocity of glucose utilization and ultimate exhaustion of energy supply. The metabolic rates among three neuroblastoma using rat, human, and mouse cell lines appear to be strikingly different in a manner consistent with the typical mouse-elephant curve for basal metabolic rate (BMR). In brief, while this study examines metabolism at the cellular level, whole body systemic energy metabolism is primarily required to produce energy to sustain cellular, organ, or systemic processes. In animals, BMR is typically measured using $\mathrm{O}_{2}$ consumption per gram per hour in the whole body at rest at neutral temperature after fasting relative to body mass (gram) where $\mathrm{BMR}=\mathrm{M}^{2 / 3}$. This also means that across all species, the BMR per gram tissue increases as animals get smaller (Sadava et al. 2003). From the data in this study on variable rates of cellular $\mathrm{O}_{2}$ consumption, it appears that species origin may play a role in varying vulnerability to the toxic effects of $\mathrm{MPP}^{+}$due to variation in base metabolic rates.

In normal respiring cells with functional mitochondria, the means by which energy is produced involves the glycolytic pathway which converts $1 \mathrm{M}$ of glucose to $2 \mathrm{M}$ of pyruvic acid, which is then transported and converted to acetyl-CoA by pyruvate dehydrogenase complex (PDHC) in the mitochondria. This is the first step in aerobic metabolism which ultimately generates reducing equivalents $\left(\mathrm{NADH}^{2} / \mathrm{FADH}^{2}\right.$ ) for entry into the electron transport to produce ATP through OXPHOS. When $\mathrm{MPP}^{+}$inhibits mitochondrial function, pyruvate is re-routed through LDH to drive SLP, supported by the data in this study where we show failure of both PDHC or pyruvate mitochondrial transporter inhibitors to reverse the protective effects of pyruvate against $\mathrm{MPP}^{+}$. These findings are also consistent with our previous findings that the protective 
affects of glucose against $\mathrm{MPP}^{+}$is not associated with reversal of OXPHOS function (Mazzio and Soliman 2003a).

Regardless of the differences between malignant neuroblastoma and normal neurons, it is believed that the major cause of $\mathrm{MPP}^{+}$toxicity and degeneration in PD is neuronal ATP depletion (Wang et al. 2007; Maruoka et al. 2007). Therefore, overcoming the loss of mitochondrial ATP production upon insult to the mitochondria could be providing neural protection. This can be achieved metabolically by augmenting the capacity of glycolysis through the administration of substrates and cofactors that drive SLP. A number of intermediates such as nicotinic acid adenine dinucleotide-reduced (NADH), pyruvate and phosphoenolpyruvate, as well as fructose, glucose, and magnesium have shown protection against $\mathrm{MPP}^{+}$in diverse neural and immortal neuroblastoma cell lines (Mazzio and Soliman 2003a, b; Jia et al. 2008; Hashimoto et al. 2008). While glucose is considered the primary energy fuel, ultimately, SLP is driven by oxidation-reduction reactions that are controlled by the availability of $\mathrm{NAD}^{+}$. In brief, $\mathrm{LDH}$ converts $\mathrm{NADH}^{+}$to $\mathrm{NAD}^{+}$, which, through glyceraldehyde-3-phosphate dehydrogenase activity, can regenerate $\mathrm{NADH}^{+}$and propel ATP production through the glycolytic enzymes phosphoglycerate kinase and pyruvate kinase. The toxicity of MPTP in animals is associated with a rise in striatal lactate (Koga et al. 2006); a drop in ATP/NAD ${ }^{+}$(Cosi and Marien 1998, 1999; Iwashita et al. 2004) and a nicotinamide deficiency exacerbate vulnerability of DAergic neurons to degenerate (Williams et al. 2005). The loss of $\mathrm{NAD}^{+}$could also occur through apoptosis which would indirectly render glycolysis inactive. For this reason, nicotinamide is protective against MPTP by attenuating the loss of $\mathrm{NAD}^{+}$incurred by pro-apoptotic poly(ADP-ribose) polymerase-I (PARP-I) activation (Cosi and Marien 1998; Schulz et al. 1995; Mukherjee et al. 1997).

In this study, it is of interest to note the absence of free radicals or antioxidant protection associated with $\mathrm{MPP}^{+}$toxicity. Our protocols did not include the use if 2,7-dichlorofluorescein diacetate (a common ROS probe) due to interferences previously noted with fluctuating amines in solution and experimental treatments. However, we did include standard ROS protocols having previously been used for quantifying specific free radicals generated by autoxidation of catecholamines or inflammation (Mazzio et al. 2004; Park and Murphy 1994). While clearly ROS play a role in inflammatory-mediated neurodegeneration, there are inconsistencies within the literature regarding a specific role for $\mathrm{MPP}^{+}$-mediated ROS neuronal damage in particular at complex I (Chinta et al. 2009). The lack of ROS effects, as mediated by MPP ${ }^{+}$, as found in this study has been reported in human SH-SY5Y cells (Caneda-Ferrón et al. 2008). Our studies also corroborate the work by Caneda-Ferrón et al. (2008) where we have reported earlier that ROS-mediated cell death is the predominant cause of catecholamine toxicity (but not $\mathrm{MPP}^{+}$) in vitro (Mazzio et al. 2004).

While a large number of studies report that $\mathrm{MPP}^{+}$induces oxidative stress in N-2A, PC-12, and mesencephalic cells, data supporting this are often evidenced by a reduction in intracellular GSH, expression or activity of SOD, catalase and glutathione peroxidase enzymes, and lipid peroxidation to which protective plant polyphenolics can attenuate toxicity (Tsai and Yin 2008; Amazzal et al. 2007; Tian et al. 2007). However, two questions emerge. (1) To what extent does exhaustion of glucose supplies within the media play a role in decline in protein synthesis or endogenous antioxidant enzyme expressions and (2) to what extent do protective antioxidants mediate effects through anti-apoptotic cell signaling systems that ultimately control supplies of $\mathrm{NAD}^{+}$and therefore glycolysis. It has been proven that a number of plantderived polyphenolics (which are also antioxidants) protect against $\mathrm{MPP}^{+}$as a result of antiapoptotic properties (i.e., resveratrol, quercetin, and luteolin) which may modulate mRNA and protein expression of Bax and Bcl-2 (Alvira et al. 2007; Wruck et al. 2007; Bournival et al. 2009). If this is the case, these antioxidants would also prevent PARP-1-induced depletion of cellular $\mathrm{NAD}^{+}$, which could otherwise halt essential redox reactions required to drive anaerobic 
glycolysis to sustain ATP (Tatton et al. 1999). Both additional supplies of glucose and antiapoptotic polyphenolics could mediate the same effects through different pathways where glucose serves to sustain ATP concentration to prevent mitochondrial transition pore (MTP) opening and polyphenolics prevent downstream associated pro-apoptotic pathways, which spare PARP-1 depletion of $\mathrm{NAD}^{+}$, thereby indirectly preventing halt of glycolysis. Both glucose and $\mathrm{NAD}^{+}$are required to drive glycolysis. For this reason, substances which prevent $\mathrm{MPP}^{+}$-mediated MPT opening, cytochrome $\mathrm{c}$ release, reduction in Bcl-2, and caspase- 3 or PARP1 activation all seem to provide protection (Pu et al. 2003; Han and Lee 2009). Ultimately, future research will be required to assess if it is the loss of ATP initiated by $\mathrm{MPP}^{+}$that initiates apoptosis which exacerbates depletion of $\mathrm{NAD}^{+}$in addition to glucose through heightened glycolysis or through ROS-mediated MTP opening and oxidative DNA damage as previously believed.

In summary, the findings in this study demonstrate that immortal cell line vulnerability to the toxicity of $\mathrm{MPP}^{+}$or hypoxia in vitro are a direct function of metabolic rate and glucose concentrations within the experimental design. These factors should be considered when interpreting toxicological findings of mitochondrial toxins or hypoxia in vitro.

\section{Acknowledgments}

This research work was supported by a grant from NIH NCRR RCMI program (G12RR 03020). Dr. Y. Soliman was supported by a faculty development grant from the RCMI program of Universidad Central del Caribe, Bayamon, PR, NIH Grant NCRR RCMI grant (G12 RR 03035).

\section{References}

Airley RE, Mobasheri A. Hypoxic regulation of glucose transport, anaerobic metabolism and angiogenesis in cancer: novel pathways and targets for anticancer therapeutics. Chemotherapy 2007;53:233-56. [PubMed: 17595539]

Alvira D, Yeste-Velasco M, Folch J, Verdaguer E, Canudas AM, Pallàs M, et al. Comparative analysis of the effects of resveratrol in two apoptotic models: inhibition of complex I and potassium deprivation in cerebellar neurons. Neuroscience 2007;147:746-56. [PubMed: 17583434]

Amazzal L, Lapôtre A, Quignon F, Bagrel D. Mangiferin protects against 1-methyl-4-phenylpyridinium toxicity mediated by oxidative stress in N2A cells. Neurosci Lett 2007;418:159-64. [PubMed: 17433543]

Basma AN, Heikkila RE, Saporito MS, Philbert M, Geller HM, Nicklas WJ. 1-Methyl-4-(2'ethylphenyl)-1,2,3,6-tetrahy-dropyridine-induced toxicity in PC12 cells is enhanced by preventing glycolysis. J Neurochem 1992;58:1052-9. [PubMed: 1737983]

Bournival J, Quessy P, Martinoli MG. Protective effects of resveratrol and quercetin against MPP(+)induced oxidative stress act by modulating markers of apoptotic death in dopaminergic neurons. Cell Mol Neurobiol 2009;29:1169-80. [PubMed: 19466539]

Burstein DE, Reder I, Weiser K, Tong T, Pritsker A, Haber RS. GLUT1 glucose transporter: a highly sensitive marker of malignancy in body cavity effusions. Mod Pathol 1998;11:392-6. [PubMed: 9578091]

Caneda-Ferrón B, De Girolamo LA, Costa T, Beck KE, Layfield R, Billett EE. Assessment of the direct and indirect effects of $\mathrm{MPP}^{+}$and dopamine on the human proteasome: implications for Parkinson's disease aetiology. J Neurochem 2008;105:225-38. [PubMed: 18021296]

Cheung YT, Lau WK, Yu MS, Lai CS, Yeung SC, So KF, et al. Effects of all-trans-retinoic acid on human SH-SY5Y neuroblastoma as in vitro model in neurotoxicity research. Neurotoxicology 2009;30:127-35. [PubMed: 19056420]

Chinta SJ, Rane A, Yadava N, Andersen JK, Nicholls DG, Polster BM. Reactive oxygen species regulation by AIF- and complex I-depleted brain mitochondria. Free Radic Biol Med 2009;46:93947. [PubMed: 19280713] 
Cosi C, Marien M. Decreases in mouse brain NAD ${ }^{+}$and ATP induced by 1-methyl-4-phenyl-1,2,3,6tetrahydropyridine (MPTP): prevention by the poly (ADP-ribose) polymerase inhibitor, benzamide. Brain Res 1998;809:58-67. [PubMed: 9795136]

Cosi C, Marien M. Implication of poly (ADP-ribose) polymerase (PARP) in neurodegeneration and brain energy metabolism. Decreases in mouse brain NAD ${ }^{+}$and ATP caused by MPTP are prevented by the PARP inhibitor benzamide. Ann N Y Acad Sci 1999;890:227-39. [PubMed: 10668429]

Evans SM, Casartelli A, Herreros E, Minnick DT, Day C, George E, et al. Development of a high throughput in vitro toxicity screen predictive of high acute in vivo toxic potential. Toxicol In Vitro 2001;15:579-84. [PubMed: 11566594]

Gatenby RA, Gawlinski ET. The glycolytic phenotype in carcinogenesis and tumor invasion: insights through mathematical models. Cancer Res 2003;63:3847-54. [PubMed: 12873971]

Godinot C, de Laplanche E, Hervouet E, Simonnet H. Actuality of Warburg's views in our understanding of renal cancer metabolism. J Bioenerg Biomembr 2007;39:235-41. [PubMed: 17665292]

Griffiths JR, McIntyre DJ, Howe FA, Stubbs M. Why are cancers acidic? A carrier-mediated diffusion model for $\mathrm{H}^{+}$transport in the interstitial fluid. Novartis Found Symp 2001;240:46-62. [PubMed: 11727936]

Han YS, Lee CS. Antidepressants reveal differential effect against 1-methyl-4-phenylpyridinium toxicity in differentiated PC12 cells. Eur J Pharmacol 2009;604:36-44. [PubMed: 19135049]

Hashimoto T, Nishi K, Nagasao J, Tsuji S, Oyanagi K. Magnesium exerts both preventive and ameliorating effects in an in vitro rat Parkinson disease model involving 1-methyl-4phenylpyridinium $\left(\mathrm{MPP}^{+}\right)$toxicity in dopaminergic neurons. Brain Res 2008;1197:143-51. [PubMed: 18242592]

Hennipman A, van Oirschot BA, Smits J, Rijksen G, Staal GE. Glycolytic enzyme activities in breast cancer metastases. Tumour Biol 1988;9:241-8. [PubMed: 2973647]

Holt A, Sharman DF, Baker GB, Palcic MM. A continuous spectrophotometric assay for monoamine oxidase and related enzymes in tissue homogenates. Anal Biochem 1997;244:384-92. [PubMed: 9025956]

Ikezaki K, Black KL, Conklin SG, Becker DP. Histochemical evaluation of energy metabolism in rat glioma. Neurol Res 1992;14:289-93. [PubMed: 1360622]

Iwashita A, Yamazaki S, Mihara K, Hattori K, Yamamoto H, Ishida J, et al. Neuroprotective effects of a novel poly (ADP-ribose) polymerase-1 inhibitor, 2-[3-[4-(4-chlorophenyl)-1-piperazinyl] propyl]-4( ${ }^{3} \mathrm{H}$ )-quinazolinone (FR255595), in an in vitro model of cell death and in mouse 1-methyl-4phenyl-1,2,3,6-tetrahydropyridine model of Parkinson's disease. J Pharmacol Exp Ther 2004;309:1067-78. [PubMed: 14985416]

Jia H, Li X, Gao H, Feng Z, Li X, Zhao L, et al. High doses of nicotinamide prevent oxidative mitochondrial dysfunction in a cellular model and improve motor deficit in a Drosophila model of Parkinson's disease. J Neurosci Res 2008;86:2083-90. [PubMed: 18381761]

Jung M, Jin G, Kim S, Kim Y, Park Y. Neuroprotective effect of methanol extract of Phellodendri Cortex against 1-methyl-4-phenylpyridinium $\left(\mathrm{MPP}^{+}\right)$-induced apoptosis in $\mathrm{PC}-12$ cells. Cell Biol Int 2009;33:957-63. [PubMed: 19524685]

Koga K, Mori A, Ohashi S, Kurihara N, Kitagawa H, Ishikawa M, Mitsumoto Y, Nakai M. H MRS identifies lactate rise in the striatum of MPTP-treated C57BL/6 mice. Eur J Neurosci 2006;23:107781. [PubMed: 16519673]

Koukourakis MI, Pitiakoudis M, Giatromanolaki A, Tsarouha A, Polychronidis A, Sivridis E, et al. Oxygen and glucose consumption in gastrointestinal adenocarcinomas: correlation with markers of hypoxia, acidity and anaerobic glycolysis. Cancer Sci 2006;97:1056-60. [PubMed: 16984378]

Liu H, Savaraj N, Priebe W, Lampidis TJ. Hypoxia increases tumor cell sensitivity to glycolytic inhibitors: a strategy for solid tumor therapy (model C). Biochem Pharmacol 2002;64:745-51. [PubMed: 12167494]

Lowry OH, Rosebrough NJ, Farr AL, Randall RJ. Protein measurement with the Folin phenol reagent. J Biol Chem 1951;193:265-75. [PubMed: 14907713]

Maruoka N, Murata T, Omata N, Takashima Y, Fujibayashi Y, Wada Y. Topological and chronological features of the impairment of glucose metabolism induced by 1-methyl-4-phenylpyridinium ion $(\mathrm{MPP}(+))$ in rat brain slices. J Neural Transm 2007;114:1155-9. [PubMed: 17431733] 
Maublant J, Vuillez JP, Talbot JN, Lumbroso J, Muratet JP, Herry JY, et al. Positron emission tomography (PET) and (F-18)-fluorodeoxyglucose in (FDG) in cancerology. Bull Cancer 1998;85:935-50. [PubMed: 9951421]

Mazzio E, Soliman KF. D-(+)-glucose rescue against 1-methyl-4-phenylpyridinium toxicity through anaerobic glycolysis in neuroblastoma cells. Brain Res 2003a;962:48-60. [PubMed: 12543455]

Mazzio E, Soliman KF. The role of glycolysis and gluconeo-genesis in the cytoprotection of neuroblastoma cells against 1-methyl 4-phenylpyridinium ion toxicity. Neurotoxicology 2003b; 24:137-47. [PubMed: 12564389]

Mazzio EA, Reams RR, Soliman KF. The role of oxidative stress, impaired glycolysis and mitochondrial respiratory redox failure in the cytotoxic effects of 6-hydroxydopamine in vitro. Brain Res 2004;1004:29-44. [PubMed: 15033417]

Mukherjee SK, Klaidman LK, Yasharel R, Adams JD Jr. Increased brain NAD prevents neuronal apoptosis in vivo. Eur J Pharmacol 1997;330:27-34. [PubMed: 9228411]

Palacios JM, Wiederhold KH. Acute administration of 1- $N$-methyl-4-phenyl-1,2,3,6-tetrahydropyridine (MPTP), a compound producing parkinsonism in humans, stimulates $\left[2-{ }^{14} \mathrm{C}\right]$ deoxyglucose uptake in the regions of the cate-cholaminergic cell bodies in the rat and guinea pig brains. Brain Res 1984;301:187-91. [PubMed: 6610458]

Palombo E, Porrino LJ, Bankiewicz KS, Crane AM, Kopin IJ, Sokoloff L. Administration of MPTP acutely increases glucose utilization in the substantia nigra of primates. Brain Res 1988;453:227-34. [PubMed: 3261197]

Pan JG, Mak TW. Metabolic targeting as an anticancer strategy: dawn of a new era? Sci STKE 2007;381:Pe14. [PubMed: 17426345]

Park SK, Murphy S. Duration of expression of inducible nitric oxide synthase in glial cells. J Neurosci Res 1994;39:405-11. [PubMed: 7533844]

Pizarro J, Junyent F, Verdaguer E, Jordan J, Beas-Zarate C, Pallàs M, Camins A, Folch J. Effects of MPP (+) on the molecular pathways involved in cell cycle control in B65 neuroblastoma cells. Pharmacol Res 2010;61:391-99. [PubMed: 20080185]

$\mathrm{Pu}$ X, Song Z, Li Y, Tu P, Li H. Acteoside from Cistanche salsa inhibits apoptosis by 1-methyl-4phenylpyridinium ion in cerebellar granule neurons. Planta Med 2003;69:65-6. [PubMed: 12567282]

Sadava, D.; Orians, GH.; Heller, CH. Life: the science of biology: volume III: plants and animals. 7th. New York: Freeman; 2003. p. 866

Schulz JB, Henshaw DR, Matthews RT, Beal MF. Coenzyme Q10 and nicotinamide and a free radical spin trap protect against MPTP neurotoxicity. Exp Neurol 1995;132:279-83. [PubMed: 7789466]

Schwartzman RJ, Alexander GM. Changes in the local cerebral metabolic rate for glucose in the 1methyl-4-phenyl-1,2,3,6-tetrahydropyridine (MPTP) primate model of Parkinson's disease. Brain Res 1985;358:137-43. [PubMed: 3878182]

Schwartzman RJ, Alexander GM, Ferraro TN, Grothusen JR, Stahl SM. Cerebral metabolism of parkinsonian primates 21 days after MPTP. Exp Neurol 1998;102:307-13. [PubMed: 3264247]

Seyfried J, Soldner F, Kunz WS, Schulz JB, Klockgether T, Kovar KA, et al. Effect of 1-methyl-4phenylpyridinium on glutathione in rat pheochromocytoma PC 12 cells. Neurochem Int 2000;36:489-97. [PubMed: 10762085]

Sullivan R, Paré GC, Frederiksen LJ, Semenza GL, Graham CH. Hypoxia-induced resistance to anticancer drugs is associated with decreased senescence and requires hypoxia-inducible factor-1 activity. Mol Cancer Ther 2008;7:1961-73. [PubMed: 18645006]

Sun W, Zhou S, Chang SS, McFate T, Verma A, Califano JA. Mitochondrial mutations contribute to HIF1alpha accumulation via increased reactive oxygen species and up-regulated pyruvate dehydrogenease kinase 2 in head and neck squamous cell carcinoma. Clin Cancer Res 2009;15:47684. [PubMed: 19147752]

Tang X, Li Y, Zhao J, Shen X, Yang C, Fan L, Hu B, Li Y, Liao D. Neuroprotective effect of asymmetrical dimethylargi-nine against 1-methyl-4-phenylpyridinium ion-induced damage in PC12 cells. Clin Exp Pharmacol Physiol. 2010 in press.

Tatton WG, Chalmers-Redman RM, Rideout HJ, Tatton NA. Mitochondrial permeability in neuronal death: possible relevance to the pathogenesis of Parkinson's disease. Parkinsonism Relat Disord 1999;5:221-9. [PubMed: 18591144] 
Tian YY, Jiang B, An LJ, Bao YM. Neuroprotective effect of catalpol against MPP(+)-induced oxidative stress in mesencephalic neurons. Eur J Pharmacol 2007;568:142-8. [PubMed: 17512520]

Tóth J. The effect of oxygenation on the biological behaviour of tumours. Orv Hetil 2007;148:1415-20. [PubMed: 17631480]

Tsai SJ, Yin MC. Antioxidative and anti-inflammatory protection of oleanolic acid and ursolic acid in PC12 cells. J Food Sci 2008;73:H174-8. [PubMed: 18803714]

Wang YM, Pu P, Le WD. ATP depletion is the major cause of $\mathrm{MPP}^{+}$induced dopamine neuronal death and worm lethality in alpha-synuclein transgenic. C elegans Neurosci Bull 2007;23:29-35.

Williams AC, Cartwright LS, Ramsden DB. Parkinson's disease: the first common neurological disease due to auto-intoxication? QJM: Int J Med 2005;98:215-26.

Wruck CJ, Claussen M, Fuhrmann G, Römer L, Schulz A, Pufe T, et al. Luteolin protects rat PC12 and C6 cells against MPP ${ }^{+}$induced toxicity via an ERK dependent Keap1-Nrf2-ARE pathway. J Neural Transm Suppl 2007;72:57-67. [PubMed: 17982879] 


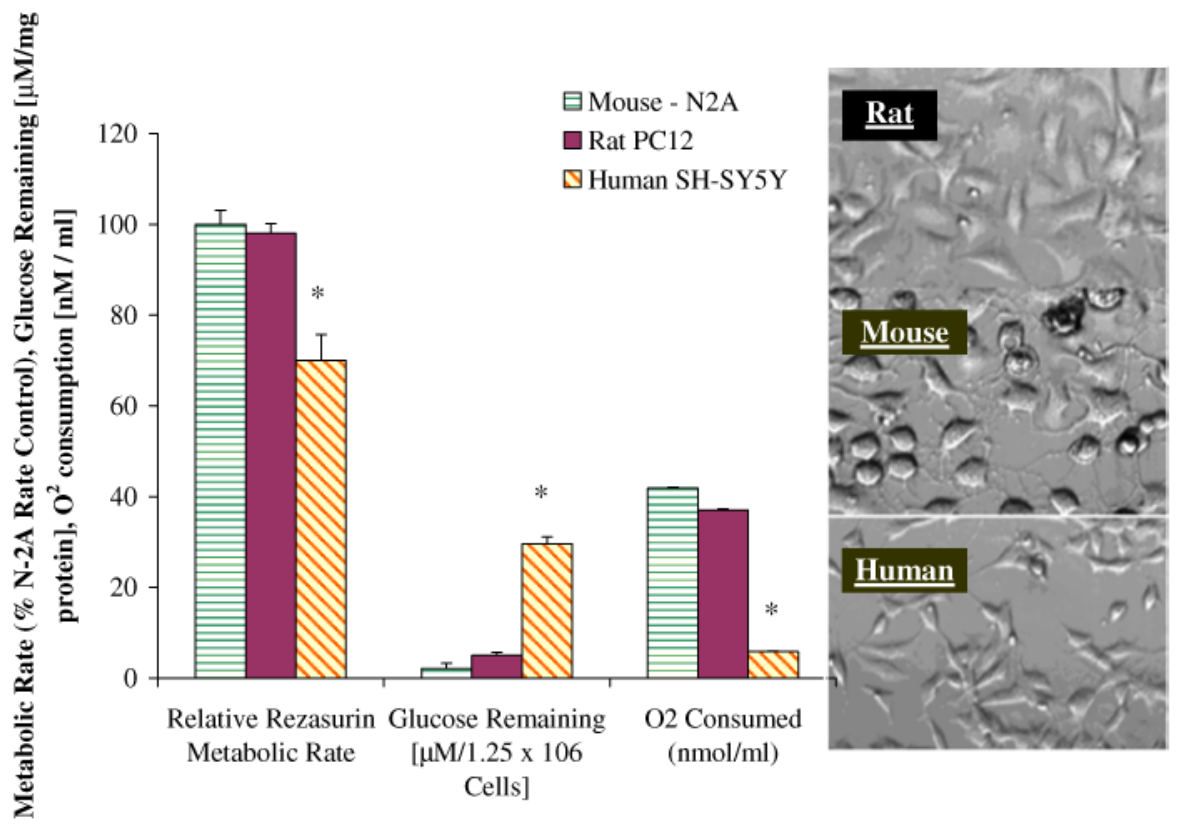

Fig. 1.

Relative metabolic rate in neuroblastoma of diverse species origin (mouse N-2A, rat PC-12, human SH-SY5Y) after $24-\mathrm{h}$ incubation at $37^{\circ} \mathrm{C}$. The data represent glucose utilization $(\mu \mathrm{M}$ glucose/cell number), dissolved $\mathrm{O}_{2}$ in the media $(\mathrm{nmol} / \mathrm{ml})$, and metabolic rate as determined by fluorescence intensity of almar blue after 4-h incubation. The data are expressed as the mean $\pm \operatorname{SEM}(N=4)$, and differences from mouse $\mathrm{N}-2 \mathrm{~A}$ cells were determined by ane-way ANOVA followed by a Tukey post hoc test. $* P<0.05$ 
a

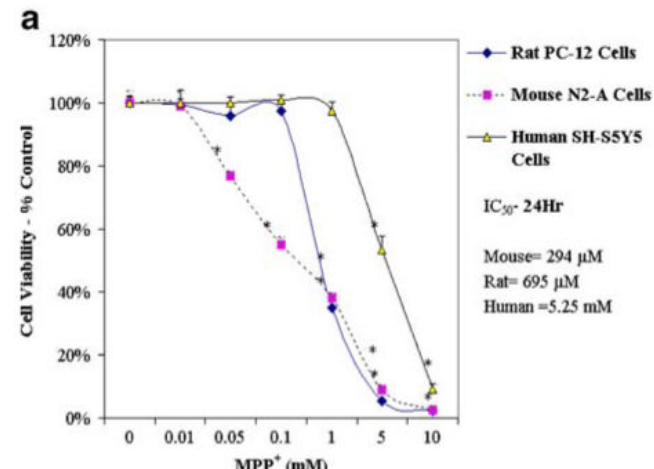

c

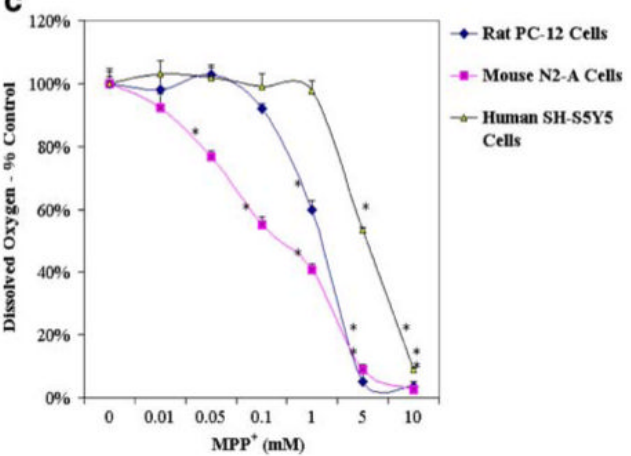

b

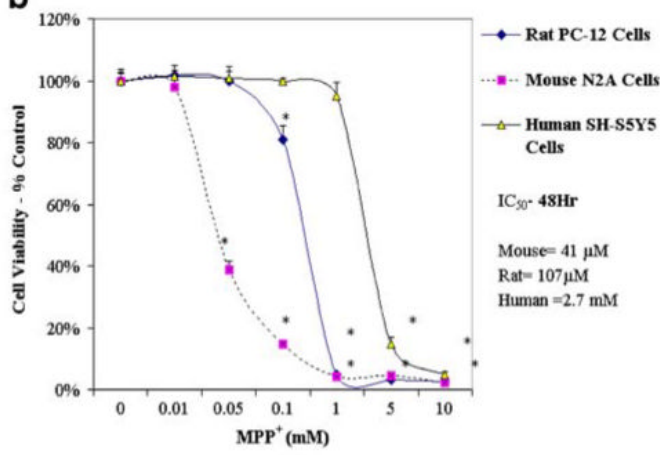

Fig. 2.

a Relative cell death in various neuroblastoma cell lines (mouse N-2A, rat PC-12, and human SH-S5Y5) after $24 \mathrm{~h} \pm \mathrm{MPP}^{+}(0-10 \mathrm{mM})$ at $37^{\circ} \mathrm{C}$. The data represent cell viability as percent untreated controls and are expressed as the mean $\pm \operatorname{SEM}(N=4)$. Statistical differences from untreated controls were determined by a one-way ANOVA followed by a Tukey post hoc test. $* P<0.05$. b Relative cell death in various neuroblastoma cell lines (mouse $\mathrm{N}-2 \mathrm{~A}$, rat $\mathrm{PC}-12$, and human SH-S5Y5) after $48 \mathrm{~h} \pm \mathrm{MPP}^{+}(0-10 \mathrm{mM})$ at $37^{\circ} \mathrm{C}$. The data represent cell viability as percent untreated controls and are expressed as the mean \pm SEM $(N=4)$. Statistical differences from untreated controls were determined by a one-way ANOVA followed by a Tukey post hoc test. $* P<0.05$. c Relative loss of mitochondrial $\mathrm{O}_{2}$ consumption in various neuroblastoma cell lines (mouse N-2A, rat PC-12, and human SH-S5Y5) after 24-h incubation $\pm \mathrm{MPP}^{+}(0-10 \mathrm{mM})$. The data represent dissolved $\mathrm{O}_{2}$ concentration in the media as percent untreated control and are expressed as the mean $\pm \operatorname{SEM}(N=4)$. A statistical difference from the control group was determined by a one-way ANOVA followed by a Tukey post hoc test. $* P<0.05$ 


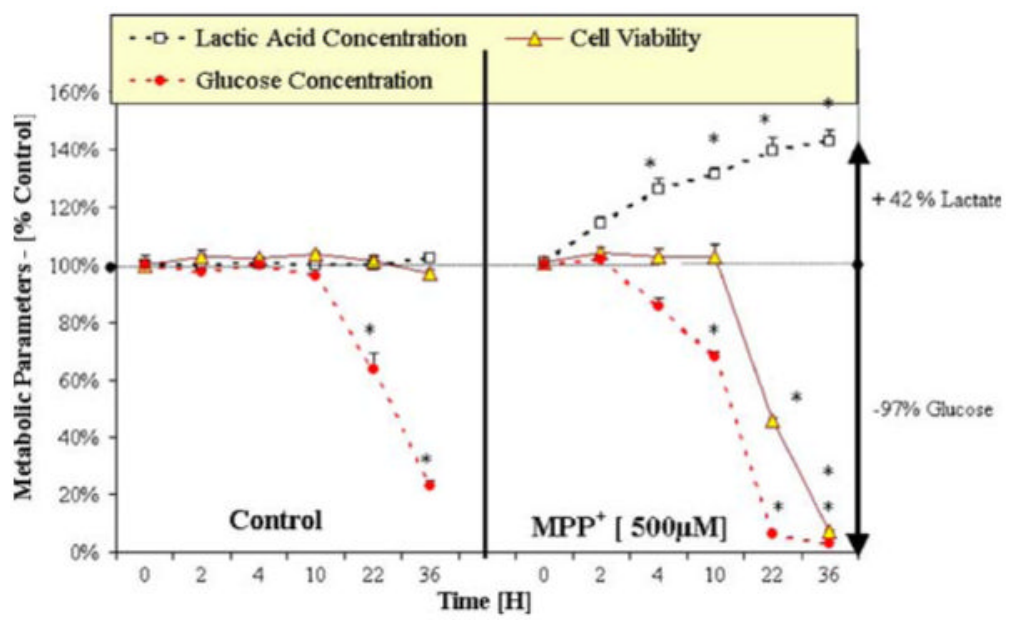

Fig. 3.

Metabolic events during time-lapse analysis of $\mathrm{MPP}^{+}(500 \mu \mathrm{M})$ toxicity in N2-A cells over 36 $\mathrm{h}$ of incubation at $37^{\circ} \mathrm{C}$. The data represent metabolic parameters (glucose concentration, lactic acid concentration, and cell viability) as percent untreated controls and are expressed as the mean \pm SEM $(N=4)$. Statistical differences from untreated controls were determined by ane way ANOVA followed by a Tukey post hoc test. $* P<0.05$ 


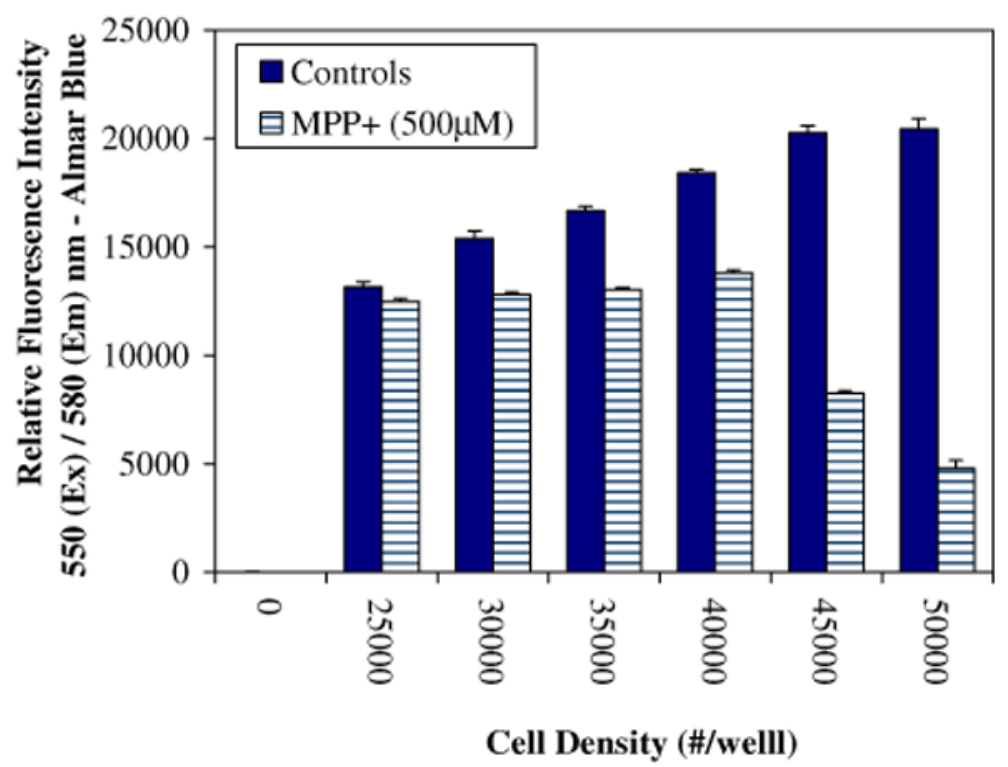

Fig. 4.

Effects of cell density on $\mathrm{MPP}^{+}$toxicity $(500 \mu \mathrm{M})$ in $\mathrm{N}-2 \mathrm{~A}$ cells after $24 \mathrm{~h}$ of incubation. The data represent cell viability as percent untreated controls and are expressed as the mean \pm SEM $(N=4)$. Statistical differences between the two groups were determined by a two-way ANOVA where $P<0.05$ 


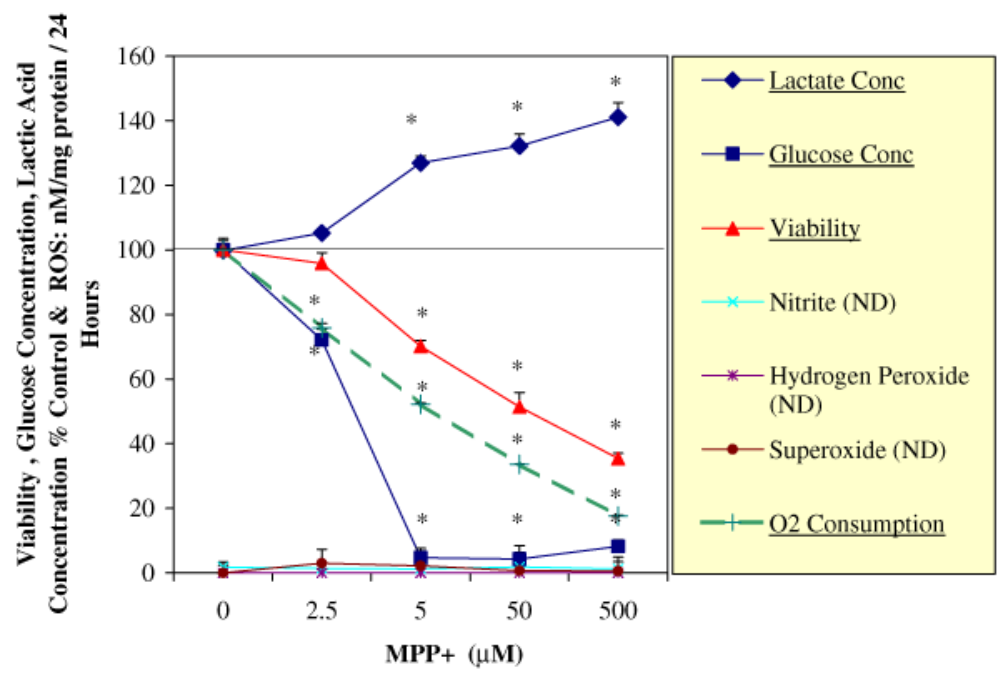

Fig. 5.

Metabolic events associated with low dose $\mathrm{MPP}^{+}(0-500 \mu \mathrm{M})$ toxicity in N2-A cells after 24 $\mathrm{h}$ of incubation at $37^{\circ} \mathrm{C}$. The data represent metabolic parameters (viability, dissolved $\mathrm{O}_{2}$, glucose remaining, lactic acid, and ROS) as percent untreated controls and are expressed as the mean $\pm \operatorname{SEM}(N=4)$. Statistical differences from the untreated controls were determined by a one-way ANOVA followed by a Tukey post hoc test. $* P<0.05$ 


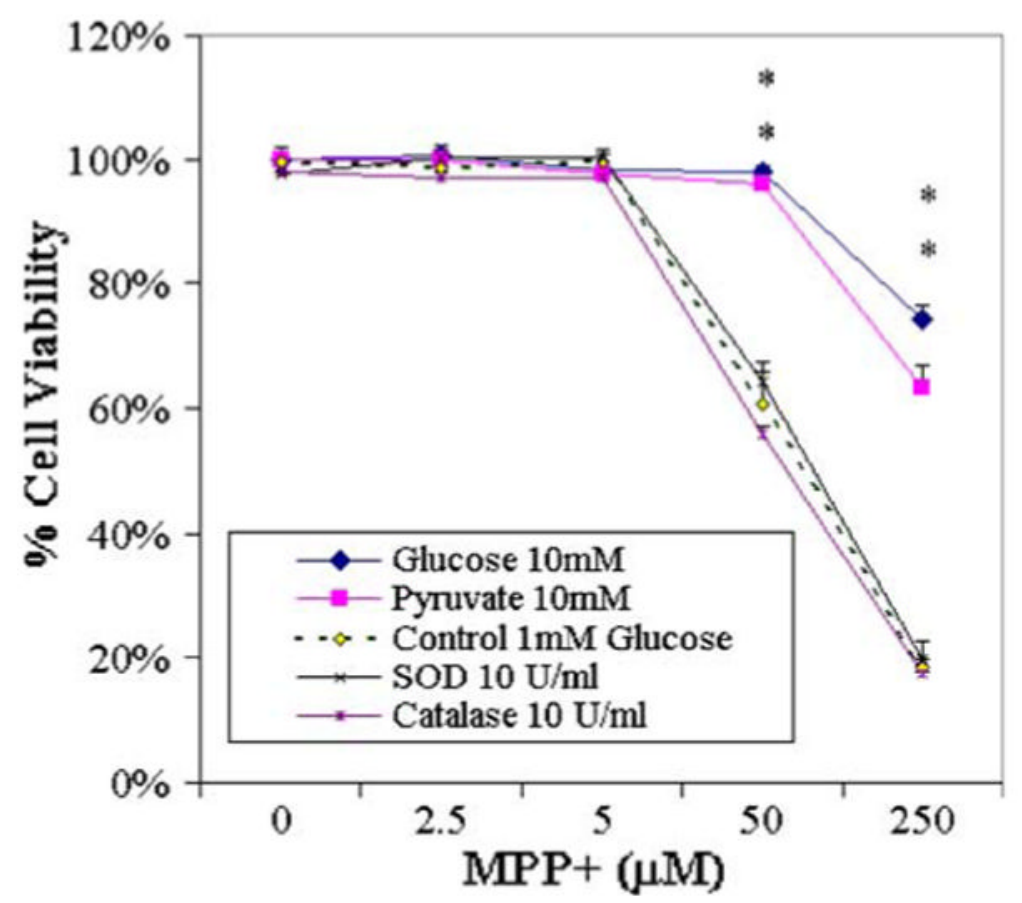

Fig. 6.

Protective effects of energy substrates or antioxidant enzymes against $\mathrm{MPP}^{+}(0-250 \mu \mathrm{M})$ toxicity in very low glucose media $(1 \mathrm{mM})$. The data represent percent control and are expressed as the mean $\pm \operatorname{SEM}(N=4)$. Statistical differences from the untreated controls were determined by a one-way ANOVA followed by a Tukey post hoc test. $* P<0.05$ 

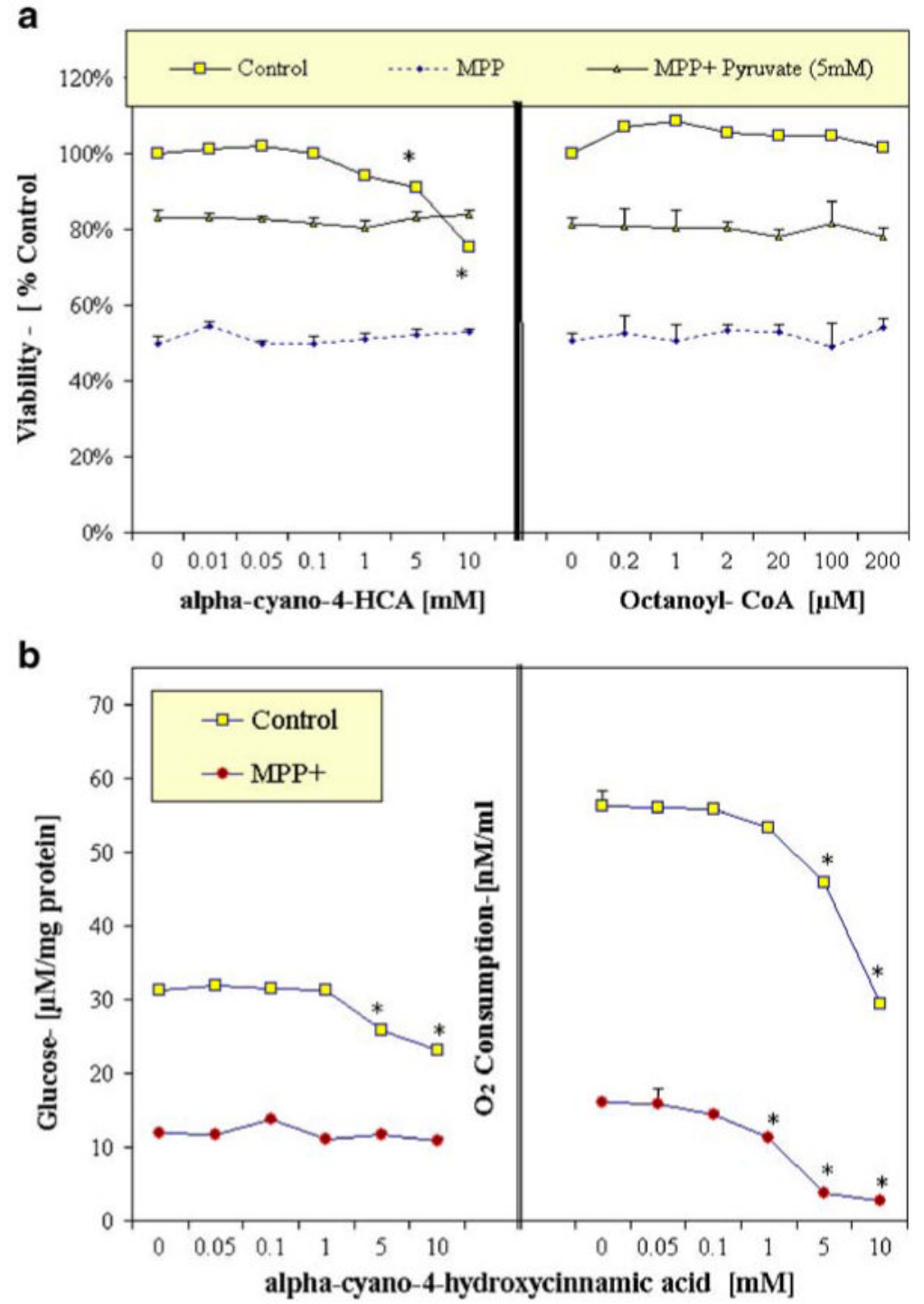

Fig. 7.

a The protective effects of pyruvate in the presence or absence of $\alpha$-cyano-4-HCA (pyruvate mitochondrial transport blocker) and octanoyl-CoA (pyruvate dehydrogenase inhibitor) against $\mathrm{MPP}^{+}$toxicity $(500 \mu \mathrm{M})$ in $\mathrm{N} 2 \mathrm{~A}$ cells after $24 \mathrm{~h}$ of incubation at $37^{\circ} \mathrm{C}$. The data represent cell viability as percent untreated controls and are expressed as the mean \pm SEM $(N=4)$. A statistical difference from the control group was determined by a one-way ANOVA followed by a Tukey post hoc test. $* P<0.05$. b The effects of $\alpha$-cyano-4-HCA (pyruvate mitochondrial transport blocker) and Octanoyl-CoA (Pyruvate dehydrogenase inhibitor) on $\mathrm{O}_{2}$ consumption and glucose utilization in $\mathrm{N} 2 \mathrm{~A}$ cells after $24-\mathrm{h}$ incubation at $37^{\circ} \mathrm{C}$. The data represent glucose utilization ( $\mu \mathrm{M}$ glucose remaining/mg protein, left panel) and $\mathrm{O}_{2}$ dissolved $\mathrm{O}_{2}$ remaining $(\mathrm{nmol} / \mathrm{ml})$ and are expressed as the mean $\pm \operatorname{SEM}(N=4)$. A statistical difference from the control group was determined by a one-way ANOVA followed by a Tukey post hoc test. $* P<0.05$ 


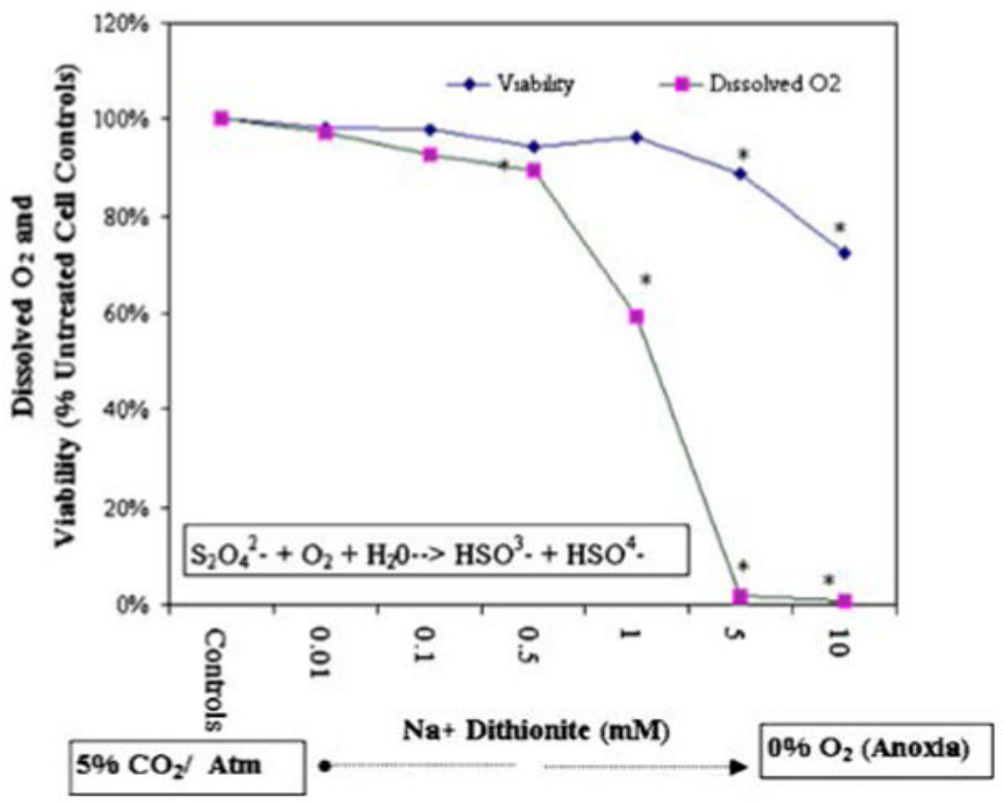

Fig. 8.

Metabolic effects of hypoxia in high glucose media $(25 \mathrm{mM})$ in the presence of varying concentration of dithionite after $24 \mathrm{~h}$ of incubation at $37^{\circ} \mathrm{C}$ in $\mathrm{N}-2 \mathrm{~A}$ cells. The data represent dissolved $\mathrm{O}_{2}(\mathrm{nmol} / \mathrm{ml})$ and metabolic rate as percent untreated controls. The data are expressed as the mean \pm SEM $(N=4)$, and differences from the controls were determined by a one-way ANOVA followed by a Tukey post hoc test. $* P<0.05$ 


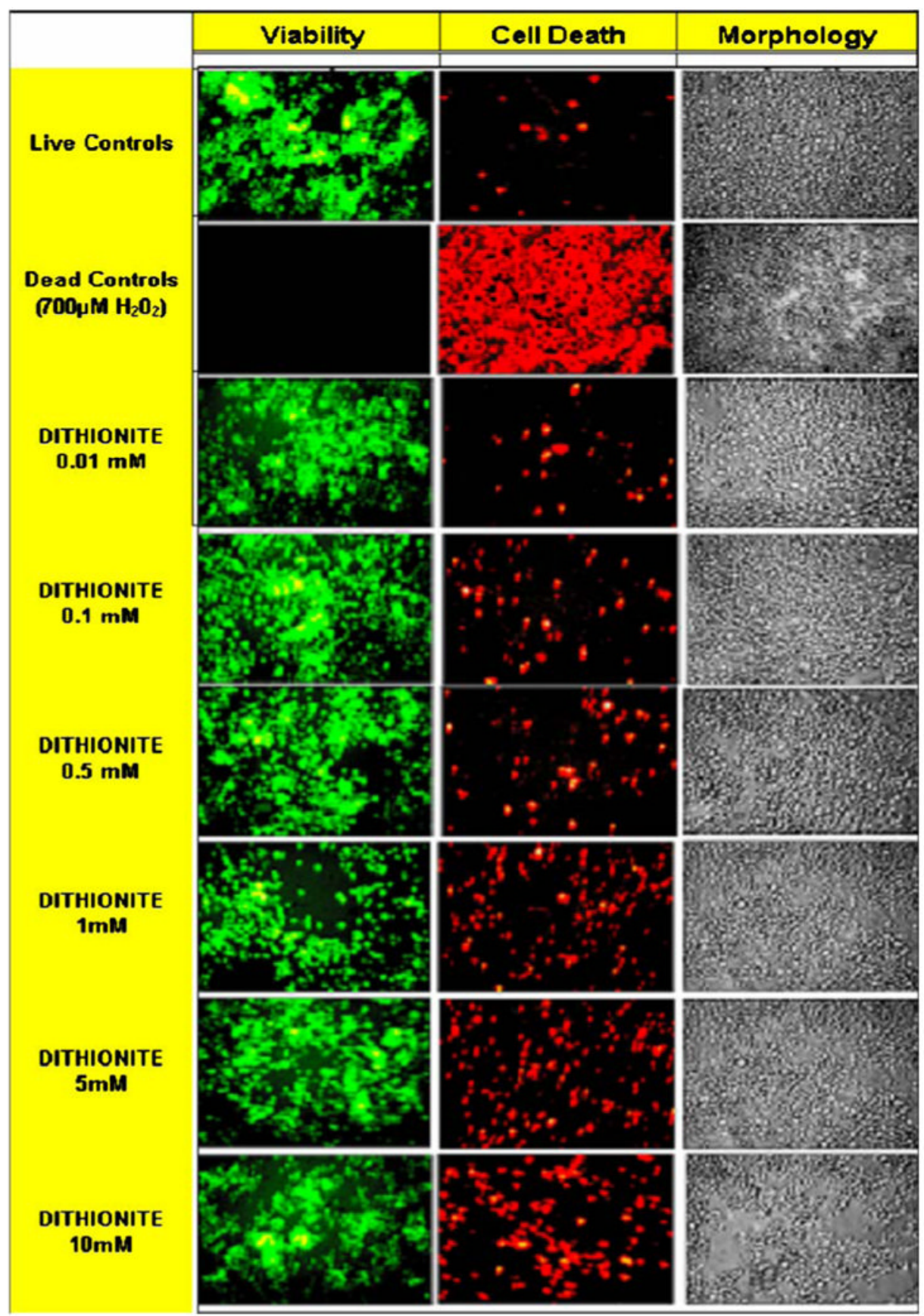

Fig. 9.

Photographic analysis of morphology (phase contrast), cell death (propidium iodide), and cell viability (fluorescein diacetate) in $\mathrm{N} 2 \mathrm{~A}$ cells after 24 -h incubation at $37^{\circ} \mathrm{C}$ with various concentrations of dithionite in high-glucose media $(25 \mathrm{mM})$. A method validation control was established by inducing cell death in $\mathrm{N} 2 \mathrm{~A}$ cell controls with $700 \mu \mathrm{M}$ of $\mathrm{H}_{2} \mathrm{O}_{2}$ 